\title{
Samarbejde møder forhindringer i Arktis
}

\author{
Af Nils Wang
}

Ukrainekrisen har endnu ikke et omfang, der kan rokke ved den stabile sikkerhedssituation i Arktis og dermed heller ikke ved det nordiske samarbejdspotentiale i denne region, men udsigterne til forøget nordisk samarbejde er i forvejen udfordret af de geografiske og realpolitiske grundvilkår.

Nordisk forsvarssamarbejde ses af mange politikere som et stort uudnyttet samarbejdsområde, der har potentiale til at løse flere af tidens store forsvars- og sikkerhedspolitiske udfordringer. I Danmark har ønsket om et øget nordisk samarbejde på forsvarsområdet fået plads $\mathrm{i}$ regeringsgrundlaget og i de øvrige nordiske lande er emnet også højt oppe på den politiske agenda. Omdrejningspunktet for denne nordiske forsvarspolitiske renæssance er blevet den såkaldte Stoltenberg rapport, der med den tidligere norske forsvars- og udenrigsminister Thorvald Stoltenberg som forfatter lister en række specifikke områder, hvor der efter hans opfattelse er muligheder for at øge samarbejdet.

Allerede i rapportens indledning an- føres det, at det er en udbredt opfattelse, at Norden får en stadig større geopolitisk betydning som følge af de nordlige farvandes rolle som produktions- og transitområde for olie og gas samt udviklingen i Arktis, og at der alene på grund af det forsvarsrelaterede ressourcebehov er et øget behov for, at de nordiske lande samarbejder. Rapporten lister herefter en række konkrete forslag til samarbejdsinitiativer, der næsten alle er karakteriseret ved at bevæge sig inden for det, man kunne kalde den 'bløde ende' af konfliktspektret.

Eksempler fra dette katalog er overvågning, kapacitetsopbygning, stabiliseringsindsatser, fælles øvelser, fælles materielindkøb osv. I det halvfulde bægers optik er rapporten visionær og dejlig konkret med fokus på de ting, der rent faktisk burde ligge inden for det muliges kunst. Omvendt kan man også se den som et relativt uambitiøst katalog over samarbejdsområder, der næsten alle er så simple og åbenbart fornuftige, at de for længst burde have været implementeret, når man betænker de utallige nordiske møder på både politisk og militært niveau, som er afholdt gennem årene.

Nils Wang er kontreadmiral og chef for Forsvarsakademiet. 


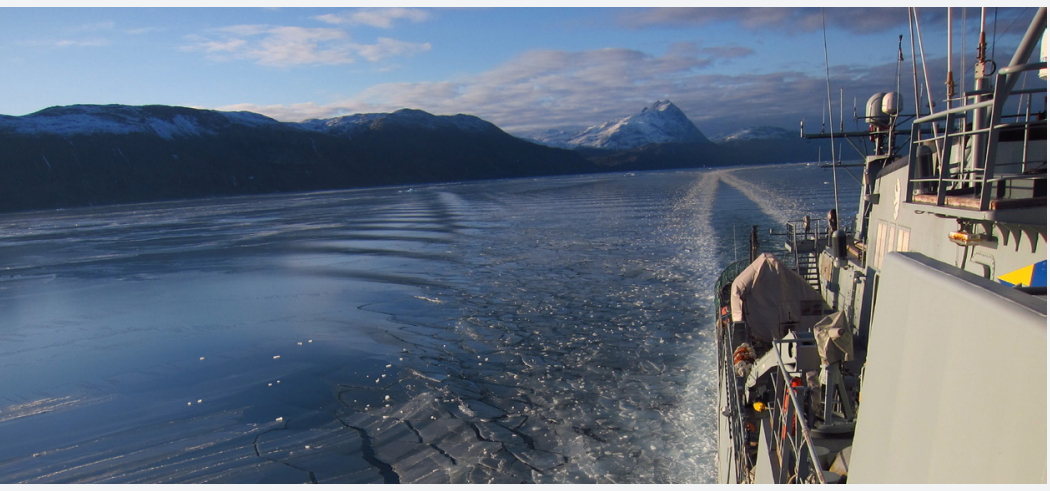
af de helt store udfordringer for en hensigtsmæssig og dækkende myndighedsudøvelse.

\section{Forskellige rammevilkår}

Når det ikke er sket, og når der skal et statsmands-ikon som Thorvald Stoltenberg til at skabe tilstrækkeligt politisk fokus på området, så er det, fordi forsvarssamarbejde i en nordisk ramme traditionelt har haft vanskelige vilkår. Trådene kan trækkes helt tilbage til mellemkrigstiden og bestræbelserne på at få etableret Nordisk Folkeforbund samt de fundamentalt forskellige sikkerhedspolitiske rammevilkår, som de fem nordiske lande fik ved Europas deling efter Anden Verdenskrig. Danmark, Norge og Island valgte en sikkerheds- og forsvarspolitisk forankring i NATO, hvorimod Sverige og Finland valgte at fortsætte neutraliteten.

Først efter den kolde krig har Sverige og Finland bevæget sig fra neutralitet til såkaldt alliancefrihed, hvor der er skabt mulighed for at samarbejde med både NATO og EU. Begge lande har dog indtil nu fortrinsvis lagt æggene i EU-forsvarskurven, hvor Norge og Island ikke er medlem, og hvor Danmark stadig har sit forsvarsforbehold. Lidt karikeret kunne man således med nogen ret hævde, at er der fem lande her på jorden, der har tradition for at se verden gennem forskellige sikkerhedspolitiske prismer, så er det de nordiske. Selv Danmark og Norge har som NATO-medlemmer set meget forskelligt på alliancens prioriteringer de seneste 10-15 år. Hvor Danmark har været advokat for, at NATO skal fokusere sin indsats ude i den store verden, har Norge på grund af af naboskabet med Rusland i nord i samme periode været bekymret for, at det skete på bekostning af alliancens fokus på og evne til territorialforsvar.

Det betones ofte, at det nordiske samarbejdspotentiale er stort, fordi de fem lande ud over geografien deler værdier og menneskesyn - altså et værdifællesskab. Det er imidlertid den sikkerhedspolitiske perception, der for alvor dikterer, i hvilken grad et land kan og vil samarbejde militært med andre, fordi sikkerheden for en nation er forudsætningen for alt andet - altså et interessefælleskab. Krisen i Ukraine har mindet os om, at det forholder sig sådan, og den har desuden skabt et forandret trusselsbillede i hele den skandinaviske region. Spørgsmålet er, hvad det betyder for det nordiske forsvarssamarbejde, herunder ikke mindst, hvad det betyder for den del af samarbejdet, der ifølge Stoltenberg rapporten er så vigtig i det arktiske område.

\section{De fleste ressourcer er fordelt}

Mere end 95 procent af de enorme olie- og gasressourcer, som findes i det arktiske område, befinder sig inden for allerede etablerede og internationalt anerkendte 'eksklusive økonomiske zoner' (EEZ ). Det betyder, at stort set alle ressourcer af værdi i dette område allerede er fordelt mellem de retmæssige ejernationer, jævnfør FN's Hav- 
retskonvention af 1982. Rusland har ratificeret denne traktat og har på grund af sin enorme arktiske kystlinje allerede fået retten til en overordentlig stor del af disse ressourcer. Rusland har desuden så sent som i 2011 indgået en ny delelinjeaftale med Norge, der har bilagt en over 30 år gammel uenighed om grænsedragningen mellem de to landes eksklusive økonomiske zoner.

Det har Rusland og Norge gjort nu, fordi det giver de to lande mulighed for at kapitalisere de betydelige energiressourcer, der ligger under havbunden i dette område. Rusland har med andre ord store økonomiske fordele af, at den internationale lovgivning på området bliver overholdt. Så store, at de få grænsemæssige uoverensstemmelser, de har med andre nationer i Arktis, er ubetydelige i dette større perspektiv. Det gælder også spørgsmålet om grænsedragningen omkring den geografiske Nordpol, hvor Rusland og Danmark forventelig vil have overlappende krav.

Udnyttelsen af disse energiressourcer og de store mineralforekomster, som befinder sig på land vil i sig selv skabe en forøget maritim trafik i området. Lægges hertil den transittrafik, som en fortsat reduktion af havisen i Polhavet vil afstedkomme, vil de polare kyststater være nødsaget til at forøge overvågningen og reguleringen af denne trafik betydeligt $\mathrm{i}$ forhold til i dag. Der vil ligeledes være behov for at styrke søredningskapacitet, havmiljøberedskab og andre kystvagtsrelaterede foranstaltninger, som knytter sig til kystområder med skibstrafik.

De barske vejrforhold og de enorme afstande der karakteriserer området, betyder, at opbygningen af denne maritime infrastruktur bliver særdeles bekostelig, og der er derfor god grund til at se sig om efter måder, hvor man kan få ressourcerne til at strække længere. Det er også grunden til, at der i Stoltenberg rapporten foreslås en fælles nordisk overvågningsindsats i området og en fælles maritim indsatsstyrke bestående af kystvagtsenheder fra de nordiske lande. Det virker umiddelbart meget logisk, fornuftigt og let gennemførligt. Men begynder man at dissekere forslagene og holder bestanddelene op imod virkeligheden, så opdager man nogle af de forhindringer, som gør, at forslagene ikke for længst er implementeret.

\section{Interesser frem for værdier}

Den første kendsgerning, man er nødt til at forholde sig til, er, at selvom alle fem nordiske lande er medlem af det efterhånden meget prestigefyldte Arktisk Råd, så har de fem nordiske lande også i Arktis vidt forskellige sikkerhedspolitiske prioriteringer og rammebetingelser. Danmark og Norge er begge kystlinjestater i Polhavet og tilhører således den del af medlemskredsen i Arktisk Råd, der går under betegnelsen 'De arktiske fem', og som også består af USA, Rusland og Canada.

Med kystlinjerne følger også retten til alle ressourcer, der befinder sig inden for den eksklusive økonomiske zone og til de ressourcer, der befinder sig på eller under havbunden inden for den såkaldte ydre kontinentalsokkelgrænse, der i disse år er ved at blive fastlagt, jævnfør reglerne i FN's Havretskonvention af 1982. Danmark og Norge har sammen med de øvrige tre arktiske kyststater skrevet under på Ilulissat Deklarationen, der i korthed går ud på, at de fem lande forpligter sig til at samarbejde og optræde som ansvarlige kyststater, men også at de påberåber sig de sø-territoriale rettigheder, som FN's Havretskonvention giver dem. Og det er denne territoriale tilknytning til Polhavet, der for Kongeriget Danmarks og Norges vedkommende gør Arktis til et spørgsmål om national suverænitet og dermed til en hård sikkerhedspolitisk prioritering baseret på interesser fremfor på værdier.

For det danske kongeriges vedkommende er der herudover den hårde sikkerhedspolitiske omstændighed, at USA 
har den strategisk vigtige Thule Base på Grønland og siden Anden Verdenskrig har betragtet Grønland som en integreret del af sin nære sikkerhedssfære. Trods beliggenhed og status som en kyststat i det arktiske område adskiller Island sig fra Danmark og Norge, idet Island ikke har kystlinje, der grænser op til Polhavet. Uagtet at Sverige og Finland er arktiske nationer og har store landområder, som befinder sig nord for Polarcirklen, så har ingen af disse to nationer kystlinje i det arktiske område, og de har dermed ikke de samme nationale sikkerhedspolitiske prioriteringer i det polare område. Omvendt har de heller ikke som underskriverne af Ilulissat deklarationen nationale forpligtelser i relation til de føromtalte kystvagtsfunktioner i de polare farvande.

\section{De store afstande}

Her kommer vi så til den første udfordring i forhold til tankerne om en fælles Nordisk Maritim Kystvagtstyrke i det Arktiske område, nemlig de økonomiske omkostninger holdt op imod de nationale prioriteringer.

Kystvagtsorganisationer er som udgangspunkt dimensioneret til de nationale behov inden for en nations søterritorium, og hvis de skal deployeres til andre landes områder, vil det ske på bekostning af den nationale opgaveløsning. Hvis et svensk eller et finsk kystvagtsskib eksempelvis skal deployere fra sit normale operationsområde i den Botniske Bugt til Barentshavet eller til det nordøstlige hjørne af Grønland, så skal det sejle mellem 4.000 og $5.000 \mathrm{~km}$. Hvis behovet skulle opstå i farvandet omkring Hansø mellem Grønland og Canada vil afstanden være godt $7.000 \mathrm{~km}$, før svenske eller finske skibe vil kunne bidrage til opgaven. Det vil være afstandsmæssigt kortere og formentlig politisk højere prioriteret for disse to nordiske lande at lade deres kystvagtsenheder deltage i FRONTEX operationer i Middelhavet.
Netop de kolossale afstande i det Arktiske område er en af de helt store udfordringer for en hensigtsmæssig og dækkende myndighedsudøvelse. 'Pooling', 'Sharing' og 'Smart Defence' er nogle af de begreber, der trækkes frem - også i Stoltenberg rapporten - når ressourcerne er knappe og behovet for effektivitet er stort. Og naturligvis er der meget at hente gennem fælles nordisk forsvarssamarbejde som fælles satellit- og radarovervågning, fælles flytransport, fælles materielstandarder, fælles indkøb og fælles øvelsesvirksomhed, herunder ikke mindst evnen til at skabe tyngde ved større ulykker eller katastrofer.

Men det giver ikke flere enheder, og dermed øger det ikke evnen til at være flere steder på en gang. Kystvagtsfunktionernes nationale karakter samt de store afstande og ansvarsområder i Arktis gør, at den enkelte nation er nødsaget til selv at sikre, at eget område er tilstrækkeligt dækket. Det er der nemlig ikke andre, der gør! Norge og Danmark har dimensioneret tilstedeværelse og suverænitetshævdelse, så der er den kystvagtsmæssige dækning, som skønnes nødvendig inden for de to landes respektive ansvarsområder i Arktis. Sverige og Finland, hvis kystvagtsorganisationer i øvrigt ikke er organiseret under forsvaret, har en kapacitet, som alene dækker deres respektive kyststatsforpligtelser i Østersøområdet.

Valg af operative samarbejdspartnere er først og fremmest dikteret af, hvem man deler område og interesser med. Kun et mindre område af den danske del af Arktis grænser op til den norske. Resten grænser op til Island og Canada. I et arktisk pooling/sharing perspektiv er lande som Rusland, Canada og USA således helt afgørende for både Norge, Danmark og Island, og samarbejdsaftaler med disse lande er formentlig i praksis langt mere effektive i tid og rum, når uheldet er ude, end tilsvarende aftaler med Sverige og Finland. 


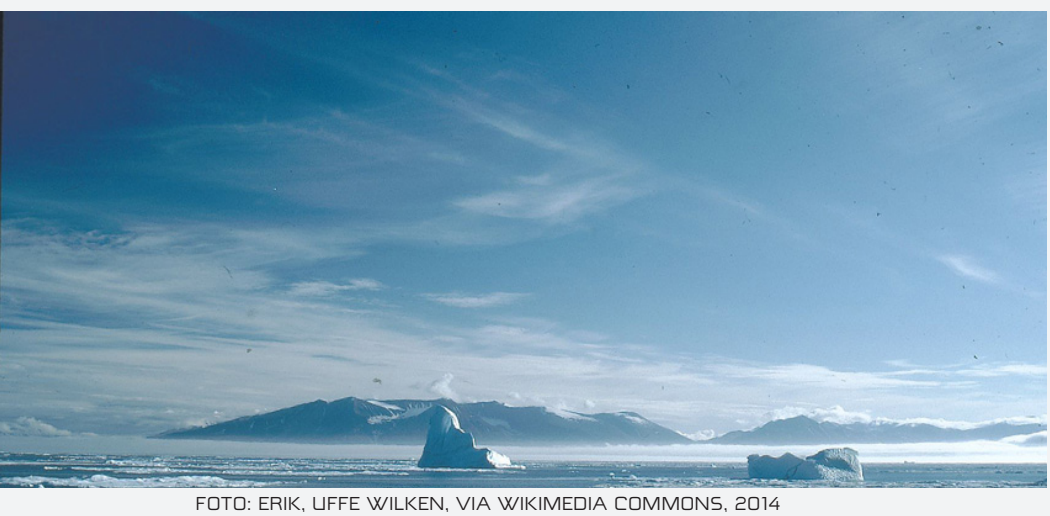
en militær kamp

Som nævnt er ressourcerne stort set fordelt, og de væsentlige grænselinjer er på plads og generelt accepteret. Forudsætningen for at de enkelte arktiske kyststater kan kapitalisere deres ressourcer er, at de kan tiltrække de store langsigtede infrastruktur-investeringer, som er nødvendige. Det gælder også for Rusland. Det kan de kun, hvis den sikkerhedspolitiske situation i området er stabil, og derfor har alle, både de som ejer ressourcerne - ikke mindst Rusland - og de som gerne vil købe dem - ikke mindst Kina - en interesse $\mathrm{i}$ at bevare et stabilt Arktis. Alt tyder således på, at kampen om ressourcerne i Arktis bliver en kommerciel kamp og ikke en militær kamp. Med stadfæstelsen af de internationale spilleregler gennem underskrivelsen af Ilulissat deklarationen og den efterfølgende optagelse af bl.a. Kina og Indien som permanente observatører i Arktisk Råd er der skabt det, man kan kalde en skrøbelig, men stabil regional ligevægtssituation.

Når man alligevel bliver nødt til at forholde sig til, at udviklingen kan gå i den forkerte retning, så skyldes det, at regionen er genstand for meget stor international interesse, herunder fra Kina, og at den omfatter to af de helt store internationale aktører, USA og Rusland. Dermed er området også udsat for en potentiel spill- over-effekt, hvis forholdet mellem disse stormagter udvikler sig dårligt i andre regioner, eller hvis der opstår stormagtspolitiske kriser andre steder, som fjerner grundlaget for dialog og samarbejde i Arktis og dermed ændrer den nuværende stabile ligevægtstilstand.

Krisen i Ukraine og det deraf affødte anspændte politiske klima mellem Rusland og den vestlige verden har næppe potentiale til at udgøre en sådan 'game changer' med mindre den udvikler sig til en direkte konfrontation mellem Rusland og NATO. Tværtimod kunne man hævde, at udsigten til en vigende europæisk lyst til at være energimæssigt afhængig af et utilregneligt Rusland på lang sigt gør det endnu mere vigtigt for Rusland at kunne sælge arktisk olie og gas til fjernøstlige markeder via russisk-arktisk infrastruktur. Krisen er imidlertid en påmindelse om, at Arktis ikke udvikler sig i isolation, men hænger sammen med udviklingen i resten af verden, og alle de gode hensigter kan blive spoleret af alvorlige hændelser og strategiske chok andre steder på kloden.

Sker det, at Arktis udvikler sig til et område præget af konflikt, så er det naturligvis ikke længere nok at se behovet for tilstedeværelse i et kystvagtsperspektiv. Det vil med overvejende sandsynlighed føre til 
en militarisering af området, og afhængig af isens udbredelse vil den være mere eller mindre konventionel. Kina vil formentlig inden for de næste 10 år være i stand til at operere med atombevæbnede ubåde under isen i Polhavet, så et koldkrigslignende scenario krydret med kinesisk deltagelse kan i givet fald ikke udelukkes. Hvis det er den udvikling, vi kommer til at se, så sker der formentlig også det, at NATO vil engagere sig, da det arktiske område jo er dækket af NATO's artikel 5 forpligtelse, og fire af de fem arktiske kyststater er medlemmer af NATO. Det vil givet udløse NATO’s tilstedeværelse i Barentshavet og langs den russiske grænse i Nordnorge, som vi kendte det under den kolde krig, og det vil forventeligt betyde, at NATO generelt vil prioritere sit territoriale forsvar, også i Østersøregionen. I et sådant scenario er vi således langt forbi det punkt, hvor det giver mening at tale om et nordisk forsvarssamarbejde med mindre Sverige og Finland i mellemtiden er blevet medlem af NATO.

\section{Sverige og Finland rører på sig}

Krisen i Ukraine har medført, at debatten om medlemskab af NATO er blusset op i både Sverige og Finland. Bevægelsen fra neutralitet til alliancefrihed og den mere operative tilnærmelse mod NATO gennem Partnerskab for Fred initiativet har således også åbnet for en debat, som ville have været utænkelig for 10 år siden. Fortsætter denne bevægelse - måske oven i købet katalyseret af de meget aggressive verbale reaktioner fra Rusland - så kan det ikke udelukkes, at de to lande på lang sigt vil blive medlemmer af Alliancen og dermed skabe det perfekte grundlag for et fuldt integreret nordisk forsvarssamarbejde. På kort sigt kan en endnu tættere operativ tilknytning til NATO være en vej, som både vil være en styrkelse af de to landes evne til at samarbejde med NATO og et stærkt, men ikke unødigt provokerende signal til Rusland i den nuværende situation.
Med dette som afsæt kunne man argumentere for, at det ændrede trusselsbillede i Østersøregionen og den potentielle mulighed for, at der på sigt kan opstå en spillover-effekt i den norsk/russiske del af Arktis, lægger op til nye samarbejdsmuligheder. Tager man udgangspunkt i Stoltenberg rapportens maritime fokus, så kunne man med inspiration fra rapportens forslag om opbygning af en fælles nordisk maritim kystvagtsstyrke - som ikke har noget NATO perspektiv - i stedet etablere en fælles nordisk sømilitær indsatsstyrke. Med Norge og Danmark som lokomotiv kunne man sikre, at styrken kan fungere som integrationsplatform til NATO for den svenske og finske flåde.

Ved en hensigtsmæssig sammensætning af styrkens ledelse, kan man sørge for, at styrken kan udsendes med eller uden svensk/finsk deltagelse, så den om nødvendigt også kan indgå som et rent NATO styrkebidrag. Samlet vil de nordiske landes flåder råde over næsten alle sømilitære kapaciteter. Med Skagerrak og Østersøen som fælles øvelsesområde med ubådsdykkefelter og adgang til betydelig flystøtte vil der kunne skabes operativ volumen til at øve alle former for sømilitær krigsførelse i nærområdet, hvilket også vil tiltrække flådeenheder fra andre NATO-lande. Uden for Østersøregionen vil Island qua sin geografiske placering kunne bidrage med øvelsesvilkår under arktiske forhold, uden at det 'militariserer' Arktis, fordi Island ikke er en del af de fem arktiske kyststater. Dermed vil man opnå et øvelsesmæssigt supplement til de øvelser under arktiske forhold, som rutinemæssig finder sted i Nordnorge. En sådan øvelsesaktivitet vil også tiltrække flådeenheder fra andre NATO-lande og således samtidigt være en kærkommen hjælp til Islands maritime suverænitetshåndhævelse, som i lighed med den fælles nordiske/NATO luftrumsovervågning vil have stor betydning for Island som nation.

Initiativet kan stort set etableres umid- 
delbart og kunne startes op på baggrund af de allerede eksisterende organisatoriske flådeledelsesstrukturer i Norge og Danmark. Hvis man opnår de ønskede resultater med initiativet, kan det senere formaliseres, eksempelvis med fælles permanent etableret ledelsesstruktur/hovedkvarter.

Sat lidt på spidsen kan man hævde, at nordisk forsvarssamarbejde har det bedst $\mathrm{i}$ fredstid og inden for områder, der ikke berører de 'hårde' sikkerhedspolitiske prioriteringer eller interesser. Det er der forklarlige historiske og geopolitiske årsager til, og et dybt og fuldt integreret nordisk forsvarssamarbejde vil således først kunne etableres, når/hvis alle fem lande bliver medlemmer af den forsvarsalliance, som Norge, Danmark og Island har forpligtet sig til. Ukrainekrisen har endnu ikke et omfang, som gør, at den kan rokke ved den stabi- le sikkerhedssituation i Arktis og dermed heller ikke ved det nordiske samarbejdspotentiale i denne region, der dog allerede i udgangspunktet er udfordret af de geografiske og realpolitiske grundvilkår.

Krisen kan imidlertid have skabt et politisk momentum i Sverige og Finland, der på kort sigt muliggør en yderligere militær NATO-integration, og på lang sigt tegner konturerne af et egentligt NATO-medlemskab. Stoltenberg-rapporten er også et godt fundament for en sådan udvikling, men hvis en tilnærmelse til NATO skal være sigtet, så bør det maritime fokus i Stoltenberg rapporten understøttes af et egentligt flådesamarbejde, som, hvis det etableres hensigtsmæssigt, kan slå mange fluer med et smæk, herunder bringe nordisk forsvarssamarbejde op i et nyt gear. 